\title{
PHOSPHORUS DYNAMICS IN DELAVAN LAKE INLET, SOUTHEASTERN WISCONSIN, 1994
}

By Dale M. Robertson, Stephen J. Field, John F. Elder, Gerald L. Goddard, and William F. James

U.S. GEOLOGICAL SURVEY

Water-Resources Investigations Report 96-4160

Prepared in cooperation with the

TOWN OF DELAVAN, WISCONSIN

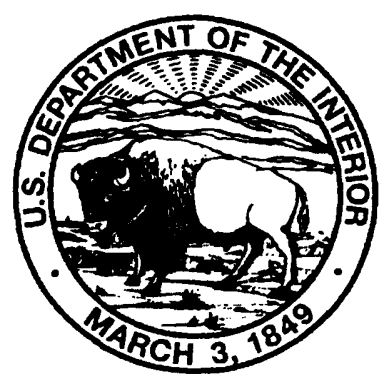

Madison, Wisconsin

1996 


\title{
U.S. DEPARTMENT OF THE INTERIOR BRUCE BABBITT, Secretary
}

\author{
U.S. GEOLOGICAL SURVEY \\ Gordon P. Eaton, Director
}

District Chief

U.S. Geological Survey

6417 Normandy Lane

Madison, WI 53719
U.S. Geological Survey

Branch of Information Services

Box 25286

Denver, CO 80225-0286 


\section{CONTENTS}

Abstract

Introduction

Methods for estimating phosphorus inputs

Runoff from gaged and ungaged areas

Ground water

Atmosphere.

Sediments of the inlet

Laboratory determination of phosphorus release rates

Ambient conditions in Delavan Lake Inlet.

Computation of phosphorus release from the sediments

Phosphorus dynamics

Background streamflow and water-quality data

Phosphorus inputs, by source, April through September 1994

Runoff from gaged and ungaged areas

Ground water

Atmosphere.

Sediments of the inlet

Total phosphorus input to and output from Delavan Lake Inlet, April through September 1994 .....

Relative importance of sources of phosphorus to Delavan Lake Inlet, April through September 1994

Accuracy of April through September phosphorus budget

Importance of the April through September loading to the annual phosphorus load to Delavan Lake

Importance of macrophytes to the phosphorus budget

Conclusions

References cited.

\section{FIGURES}

1. Map showing data-collection sites in Delavan Lake subbasins, Wisconsin, 1993-94

2-9. Graphs showing:

2. Volumetrically-averaged total phosphorus concentrations in Delavan Lake, Wisconsin, 1983-94

3. Median May-through-October total phosphorus concentrations in Delavan Lake Inlet at State Highway 50, Wisconsin, 1984-94.

4. Daily average flow at Mound Road and daily average water temperature, dissolved oxygen, and $\mathrm{pH}$

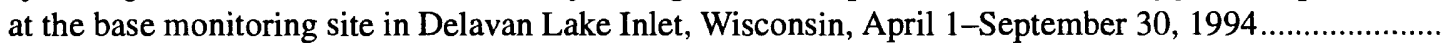

5. Total phosphorus concentrations in Delavan Lake Inlet, Wisconsin, April 14-September 30, 1994 ..............

6. Total phosphorus loading into Delavan Lake Inlet, Wisconsin summarized by day and month....................

7. Summary of total phosphorus budget for Delavan Lake Inlet, Wisconsin, April 14-September 30, 1994, and October 1, 1993-September 30, 1994

8. Cumulative phosphorus loading into and out of Delavan Lake Inlet, Wisconsin, April 14-September 30, 1994

9. Measured and estimated total phosphorus concentrations in Delavan Lake Inlet, Wisconsin, April 14-September 30, 1994

\section{TABLES}

1. Remedial efforts in the Delavan Lake Basin, Wisconsin

2. Detailed phosphorus budget for Delavan Lake Inlet, Wisconsin, April 14-September 30, 1994 ....................... 12

3. Phosphorus budget for Delavan Lake Inlet, Wisconsin, February 1993-September 1994 


\begin{tabular}{rll}
\hline Multiply & By & To Obtain \\
meter $(\mathrm{m})$ & & foot \\
kilometer $(\mathrm{km})$ & 3.2808 & mile \\
milligram $(\mathrm{mg})$ & .6215 & pound \\
kilogram $(\mathrm{kg})$ & .0000022045 & pound \\
cubic feet per second $\left(\mathrm{ft}^{3} / \mathrm{s}\right)$ & 2.2045 & cubic meter per second \\
liter $(\mathrm{L})$ & .0283 & gallon \\
centimeter $(\mathrm{cm})$ & .26417 & foot \\
square meter $\left(\mathrm{m}^{2}\right)$ & .032808 & square foot \\
cubic meter $\left(\mathrm{m}^{3}\right)$ & 10.76391 & gallon \\
cubic meter per second $\left(\mathrm{m}^{3} / \mathrm{s}\right)$ & 264.17205 & cubic feet per second
\end{tabular}

Degree Celsius $\left({ }^{\circ} \mathrm{C}\right)$ may be converted to degree Fahrenheit $\left({ }^{\circ} \mathrm{F}\right)$ by using the following equation:

$$
{ }^{\circ} \mathrm{F}=1.8\left({ }^{\circ} \mathrm{C}\right)+32
$$

\begin{abstract}
Abbreviated water-quality units used in this report: Chemical concentrations and water temperature are given in metric units. Chemical concentration is given in milligrams per liter $(\mathrm{mg} / \mathrm{L})$. Milligrams per liter is a unit expressing the concentration of chemical constituents in solution as weight (milligrams) of solute per unit volume (liter) of water. For concentrations less than $7,000 \mathrm{mg} / \mathrm{L}$, the numerical value is the same as for concentrations in parts per million. Milligrams per kilogram $(\mathrm{mg} / \mathrm{kg}$ ) is a unit expressing the concentration of a chemical constituent in the solid phase as mass (milligrams) of constituent per unit mass (kilograms) of dry sediment.
\end{abstract}

\title{
ACKNOWLEDGMENTS
}

\section{Technical Reviewers}

Herbẹrt S. Garn, Supervisory Hydrologist, U.S. Geological Survey, Madison, Wis.

Daniel R. Helsel, Southeast District Water Resource Specialist, Wisconsin Department of Natural Resources, Milwaukee, Wis.

\section{Editorial and Graphics}

C. Michael Eberle, Technical Publications Editor, U.S. Geological Survey, Columbus, Ohio

Billy Robinson, Editor, U.S. Geological Survey (Retired), Denver, Colo.

Karen Barr, Secretary, U.S. Geological Survey, Madison, Wis.

Ross Bagwell, Office Automation Clerk, U.S. Geological Survey, Madison, Wis.

Scott Linder, Hydrologic Technician, U.S. Geological Survey, Madison, Wis.

Susan Ziegler Jones, Editorial Assistant, U.S. Geological Survey, Madison, Wis.

Michelle M. Greenwood, Cartographer, U.S. Geological Survey, Madison, Wis.

\section{Cover Photo}

Southeastern Wisconsin Regional Planning Commission, Photography by Geonex Chicago Aerial Survey, Inc., Des Plaines, Illinois 


\title{
Phosphorus Dynamics in Delavan Lake Inlet, Southeastern Wisconsin, 1994
}

\author{
By Dale M. Robertson ${ }^{1}$, Stephen J. Field ${ }^{1}$, John F. Elder ${ }^{1}$, Gerald L. Goddard ${ }^{1}$, and \\ William F. James ${ }^{2}$
}

\section{Abstract}

Removal of rough fish from Delavan Lake Inlet in southeastern Wisconsin transformed the inlet from a shallow, turbid-water system with few macrophytes to a clear-water system with an abundance of macrophytes and increased phosphorus concentrations. To understand the changes in the phosphorus dynamics, the U.S. Geological Survey and the U.S. Army Corps of Engineers, in cooperation with the Town of Delavan, constructed a detailed phosphorus budget for the inlet for April through September 1994. The budget included inputs from the drainage basin, atmosphere, sediments (as a function of $\mathrm{pH}$ and the fraction of the day under anoxic conditions), and ground water. Laboratory studies estimated phosphorus flux rates under various conditions. Field studies documented ambient conditions in the inlet and fluxes of phosphorus into and out of the inlet. Phosphorus released from the sediments was estimated by coupling the flux rates, estimated in the laboratory, with ambient conditions in the inlet.

The detailed phosphorus budget indicated that the increase in phosphorus concentrations was caused primarily by elevated $\mathrm{pH}$ resulting from increased photosynthetic activity of the macrophytes and a high release of phosphorus from the sediments. The release of phosphorus from the sediments was the largest source of phosphorus to the inlet in the spring and summer of 1994 and in other years of low to near normal runoff; however, in years of high runoff, phosphorus input from the inlet's drainage basin was the largest source of phosphorus. A less-detailed phosphorus budget constructed for the period from February 1993 to September 1994 demon- strated that, over the entire year, runoff from the drainage basin was the dominant source in the phosphorus budget. During April-September 1994, the input of phosphorus from the inlet may especially affect the summer productivity in Delavan Lake because almost 80 percent of the phosphorus loading during this time was in the form of dissolved orthophosphate.

\section{INTRODUCTION}

Delavan Lake is a eutrophic lake in southeastern Wisconsin. In recent years, eutrophication has accelerated primarily because of excessive phosphorus loading from the lake's watershed (Wisconsin Department of Natural Resources, 1989). From the late 1950's until 1990 eutrophication in Delavan Lake was in the form of excessive algae; since then, it has primarily taken the form of excess macrophytes and filamentous algae.

The principal surface-water tributary to Delavan Lake is Jackson Creek, which enters through Delavan Lake Inlet on the northeastern end of the lake (fig. 1). The inlet is $2.9 \mathrm{~km}$ long and as much as $0.32 \mathrm{~km}$ wide. Most of the inlet is less than $1 \mathrm{~m}$ deep, except for a 1.5-m-deep dredged channel in the downstream part. Jackson Creek, which represents about 50 percent of the Delavan Lake Basin, drains extensive agricultural areas and the developing areas of the city of Elkhorn and until 1981, received effluent from the sewage-treatment plant at Elkhorn. The input from this sewage-treatment plant was the source of about 60 percent of the external phosphorus input to the lake (U.S. Environmental Protection Agency, 1974). Within the inlet, stream velocities decrease from those of the upstream tributary and have resulted in an accumulation of fine sediments and nutrients. The total phosphorus concentrations of sediments

\footnotetext{
${ }^{1}$ U.S. Geological Survey, Madison, Wis.

${ }^{2}$ U.S. Army Corps of Engineers, Waterways Experiment Station, Eau Galle Aquatic Ecology Laboratory, Spring Valley, Wis.
} 


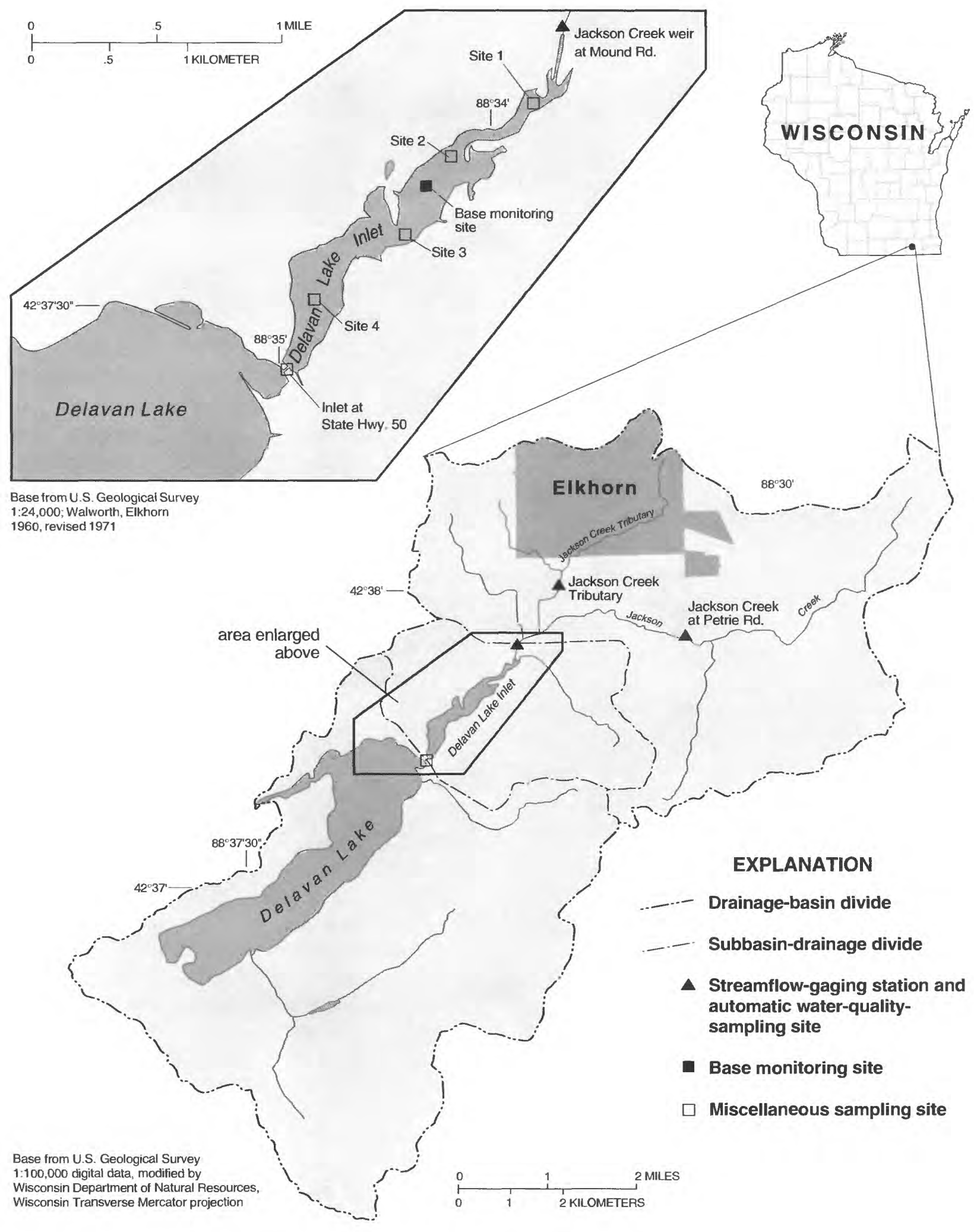

Figure 1. Data-collection sites in Delavan Lake subbasins, Wisconsin, 1993-94. 
Table 1. Remedial efforts in the Delavan Lake Basin, Wisconsin ${ }^{1}$

\begin{tabular}{|c|c|}
\hline Completion date & Remedial effort \\
\hline Fall 1981 & Diversion of all sewage-treatment effluent and sewering of nearby residents. \\
\hline 1986 & Controlled release of phosphorus from a fertilizer plant and distribution center in Elkhorn, Wis. \\
\hline Fall 1989 & Drawdown of Delavan Lake by $3.3 \mathrm{~m}$ and rotenone applied to eradicate fish. \\
\hline Winter 1989 & $\begin{array}{l}\text { Peninsula at inlet extended approximately } 200 \mathrm{~m} \text { and dam outlet operation modified to increase } \\
\text { short-circuiting of inflow. Lake filled to normal level. }\end{array}$ \\
\hline Spring 1990 & $\begin{array}{l}\text { Alum applied to lake to remove phosphorus from water column and to inhibit the release of } \\
\text { phosphorus from the sediments during periods of oxygen depletion. }\end{array}$ \\
\hline Spring 1990 & Fish restocked in lake. \\
\hline 1993 & Wetlands constructed upstream from inlet. \\
\hline Ongoing & Best Management Practices implemented throughout basin. \\
\hline
\end{tabular}

${ }^{1}$ See Helsel and MacKinnon (1995) for a complete discussion of remedial efforts in the Delavan Lake Basin.

in Delavan Lake Inlet are extremely high, ranging from 1,000 to $2,300 \mathrm{mg} / \mathrm{kg}$ (Field and Duerk, 1988); such concentrations are well above $650 \mathrm{mg} / \mathrm{kg}$ considered by the U.S. Environmental Protection Agency (1977) to be indicative of "heavily polluted" water.

After all sewage-treatment effluent was diverted from the Jackson Creek Basin in 1981 and all homes and businesses within $0.5 \mathrm{~km}$ of the lakeshore were sewered, Delavan Lake remained eutrophic. In fact, the worst blue-green algal bloom during the summer of 1983 was among the densest on record; however, phosphorus concentrations in the lake appeared to be decreasing (fig. 2). After the diversion, a nutrient budget computed for the lake and its drainage basin for water years ${ }^{3}$ 1984-85 (Field and Duerk, 1988) showed that 75 percent of its external phosphorus, 62 percent of its external Kjeldahl nitrogen, and 58 percent of its external nitrate plus nitrite was still from Delavan Lake Inlet. Approximately 20 percent of the total phosphorus was in the form of dissolved orthophosphate. The persisting phosphorus loads were shown to be excessive and sufficient to maintain eutrophy in the lake (Field and Duerk, 1988).

Since 1981, a wetland has been constructed in the Delavan Lake Basin, various Best Management Practices have been implemented upstream from Delavan Lake Inlet, and rough fish have been eradicated within the lake and inlet (table 1). Changes in the vol-

\footnotetext{
${ }^{3}$ Water year in U.S. Geological Survey reports is the $12-$ month period, October 1 through September 30 . The water year is designated by the calendar year in which it ends and which includes 9 of the 12 months. Thus, the year ending September 30, 1993 is called "1993 water year."
}

umetrically-averaged total phosphorus concentrations in Delavan Lake from 1983 to 1994 are shown in figure 2 . With the removal of rough fish in 1989 , the clarity of shallow Delavan Lake Inlet (which was as low as about $0.2 \mathrm{~m}$ in summer 1984) improved substantially; macrophytes formed dense stands throughout the inlet that further decreased flow velocities and increased sediment retention. Yet, even after remedial activities upstream from Delavan Lake Inlet, increases in phosphorus concentration were documented within the inlet. Median May-through-October total phosphorus concentrations, that had been about $0.3 \mathrm{mg} / \mathrm{L}$ prior to 1991 , increased to about $0.7 \mathrm{mg} / \mathrm{L}$ and remained elevated through 1994 (fig 3). Field reconnaissance by the U.S. Geological Survey (USGS) and the Wisconsin Department of Natural Resources found no visible point or nonpoint sources of phosphorus that could explain the increase in concentration. In a short-term investigation from May through July in 1993, the USGS found that the increases in phosphorus concentrations did not appear to be related to boating or weed harvesting. The investigators hypothesized that the increased phosphorus concentrations may have been caused by an increased phosphorus release from the sediments during periods of anoxia (depletion of dissolved oxygen).

In order to identify the cause of the elevated phosphorus concentrations, the USGS and the U.S. Army Corps of Engineers, in cooperation with the Town of Delavan, conducted a study to describe the phosphorus dynamics in Delavan Lake Inlet and to determine the major sources of phosphorus to the inlet and ultimately to Delavan Lake. This report gives the 


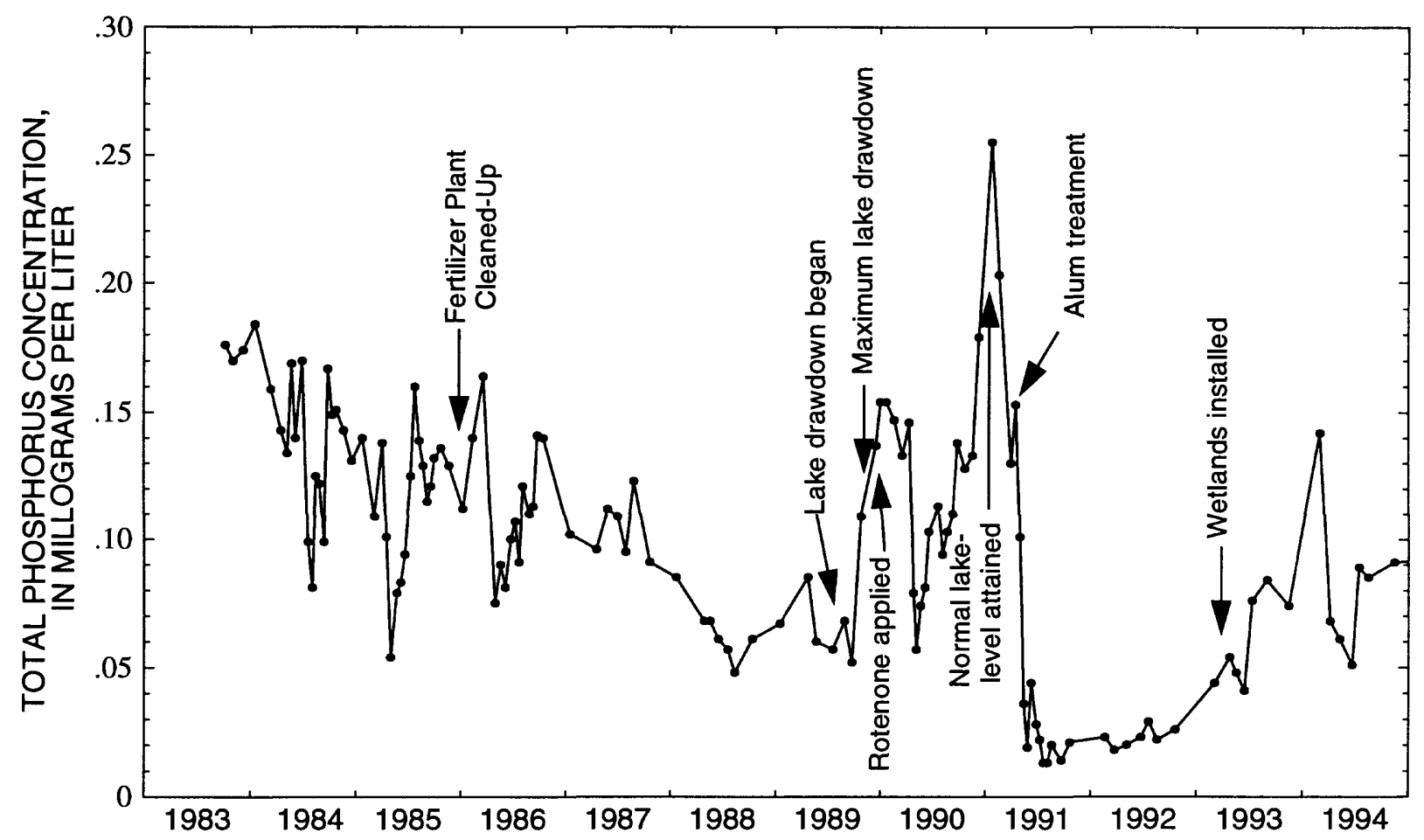

Figure 2. Volumetrically-averaged total phosphorus concentrations in Delavan Lake, Wisconsin, 1983-94.

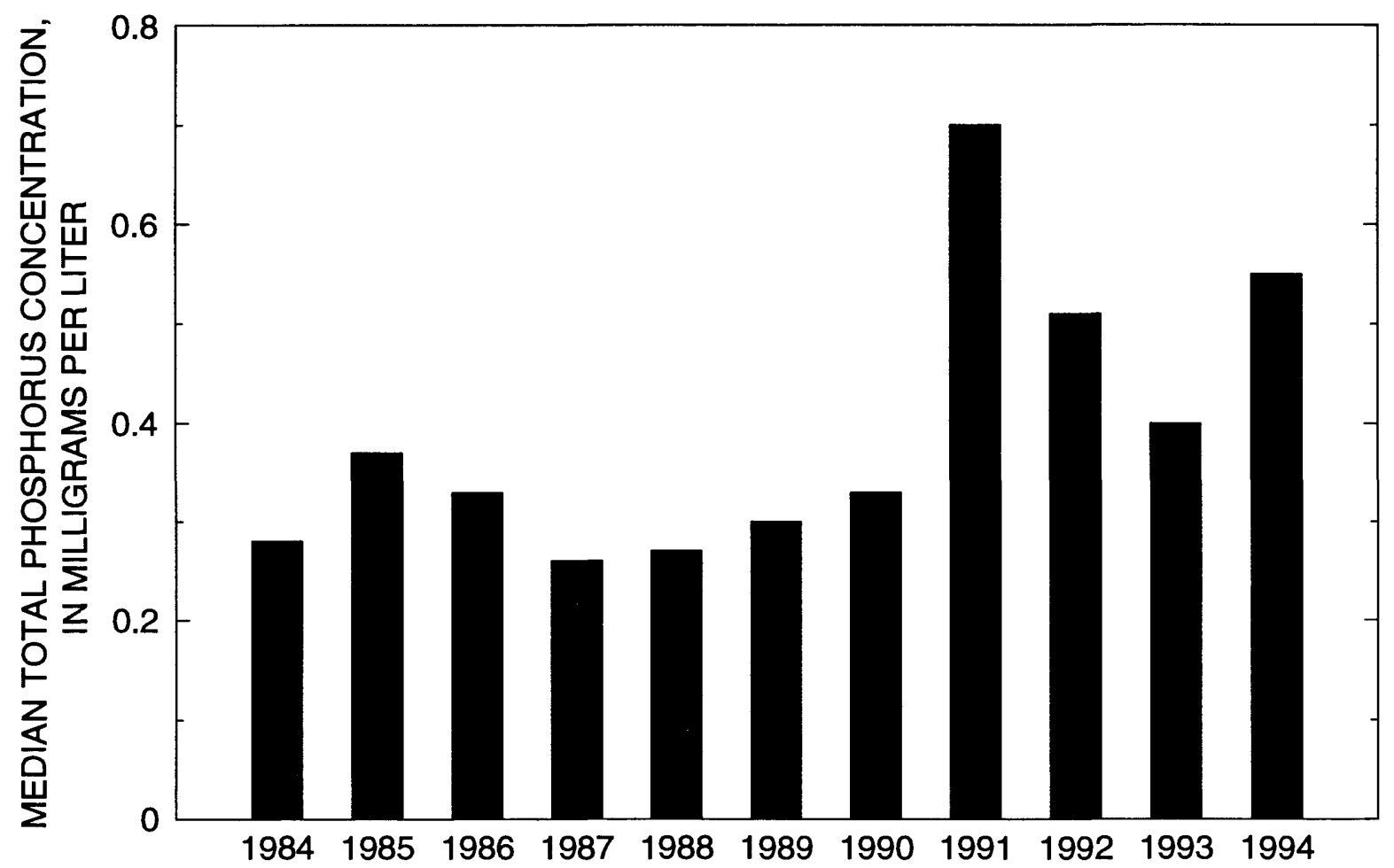

Figure 3. Median May-through-October total phosphorus concentrations in Delavan Lake Inlet at State Highway 50, Wisconsin, 1984-94. 
results of that study. A clear understanding of the phosphorus dynamics in this shallow aquatic system should be useful for making decisions on remedial actions in the Jackson Creek Basin and perhaps for restoring and managing other shallow aquatic environments.

\section{METHODS FOR ESTIMATING PHOSPHORUS INPUTS}

To describe the phosphorus dynamics, a detailed total phosphorus budget was prepared for the inlet for April 14 through September 30, 1994 (eq. 1) and a less detailed budget for the inlet for February 1993 through September 1994 (eq. 2).

$$
\begin{gathered}
\mathrm{P}_{\mathrm{G}}+\mathrm{P}_{\mathrm{UG}}+\mathrm{P}_{\mathrm{GW}}+\mathrm{P}_{\mathrm{Atm}}+\mathrm{P}_{\mathrm{SO}}+\mathrm{P}_{\mathrm{SA}}+\Delta \mathrm{S}=\mathrm{P}_{\mathrm{Out}} \\
\mathrm{P}_{\mathrm{G}}+\mathrm{P}_{\mathrm{UG}}+\mathrm{P}_{\mathrm{GW}}+\mathrm{P}_{\mathrm{Atm}}+\Delta \text { Inlet }=\mathrm{P}_{\mathrm{Out}}
\end{gathered}
$$

The detailed budget includes phosphorus input to the inlet from the upstream watershed by way of Jackson Creek (gaged area, $\mathrm{P}_{\mathrm{G}}$ ), direct runoff (ungaged areas, $\left.\mathrm{P}_{\mathrm{UG}}\right)$, ground water $\left(\mathrm{P}_{\mathrm{GW}}\right)$, atmosphere $\left(\mathrm{P}_{\mathrm{Atm}}\right)$, and inlet sediments during oxic periods $\left(\mathrm{P}_{\mathrm{SO}}\right)$ and anoxic periods $\left(\mathrm{P}_{\mathrm{SA}}\right)$, and phosphorus output from the inlet to Delavan Lake $\left(\mathrm{P}_{\text {Out }}\right)$. The difference between that input to the inlet and output from the inlet should be equal to the change in the amount of phosphorus in the inlet $(\Delta S)$. Because all of the terms in equation 1 except the $\Delta S$ term were estimated, the $\Delta S$ term represents the change in the amount of phosphorus in the inlet and the net error of all the terms in the entire budget. In the less-detailed budget, the input of phosphorus from the sediment and the change in storage are combined into one term, the change in the amount of phosphorus in the inlet ( $\Delta$ Inlet). Preparation of a lessdetailed budget allowed the authors to evaluate the significance of the summer input of phosphorus to the annual load to Delavan Lake during 1993 and 1994.

\section{Runoff from Gaged and Ungaged Areas}

Continuous streamflow into the inlet was monitored at Mound Road (fig. 1) by continuously recording water levels at a v-notched weir and computing flow by use of a stage-discharge relation. Streamflow out of the inlet into Delavan Lake at State Highway 50 could not be measured by use of conventional methods because of variable backwater from the lake; therefore, streamflow was estimated by use of a drainage-area relation applied to Mound Road data. (Streamflow at Highway
$50=$ streamflow at Mound Road X 1.3; the drainage area at State Highway 50 is 1.3 times that of the drainage area at Mound Road.)

Water samples collected from Jackson Creek at Petrie Road, Mound Road, and State Highway 50, and Jackson Creek Tributary (fig. 1) were analyzed for total phosphorus and dissolved orthophosphate. At these sites, except State Highway 50, storm-runoff samples were collected by means of stage-activated, refrigerated, automatic samplers. Samples were also collected manually by use of the equal-width increment (EWI) method described by Guy and Norman (1970). EWI samples, collected at the times that samples were collected by the automated samplers, were used to develop coefficients to correct for differences in concentration between point samples collected by the automatic samplers and the more representative, flow- and cross-sectionally-integrated EWI samples. EWI samples were collected during low flows at all sites to estimate phosphorus transport between storms. Additional EWI samples were collected at State Highway 50 during runoffproducing storms (usually two samples per day were collected during the storms). All chemical analyses were done by the USGS in accordance with standard analytical procedures described by Fishman and Friedman (1988). Dissolved orthophosphate was determined for samples that were filtered through a membrane with a pore diameter of $0.45 \mu \mathrm{m}$. Preservation and shipment of samples followed standard protocols established by the USGS laboratory. All flow and water-quality data were published in Holmstrom and others $(1994,1995)$.

Daily phosphorus loads entering $\left(\mathrm{P}_{\mathrm{G}}\right)$ and leaving the inlet $\left(\mathrm{P}_{\text {Out }}\right)$ were computed for February 1993September 1994 by use of the integration method described by Porterfield (1972); the data are reported in Holmstrom and others $(1994,1995)$. Daily phosphorus loads from direct runoff into the inlet $\left(\mathrm{P}_{\mathrm{UG}}\right)$ were calculated by multiplying the daily average total phosphorus concentrations measured at Petrie Road by an estimate of the additional inflow into the inlet $(0.3$ times the streamflow at Mound Road). Phosphorus concentrations at Petrie Road were used to represent those for direct runoff because of the similar land-use practices in the two areas.

\section{Ground Water}

Phosphorus input from ground water, $\left(\mathrm{P}_{\mathrm{GW}}\right)$, was estimated from samples collected from seepage 
meters placed into the bottom sediments at five locations in the inlet from June through September 1994. The seepage meters were installed for 1- to 3-week intervals at the base monitoring site, chosen to characterize the conditions in the inlet and located midway between the weir at Mound Road and the outlet to the lake, and at four additional sites (sites 1-4, fig.1). The seepage meters were placed into the sediments near the base monitoring site during each sampling period and at each of the other sites on a rotational basis. For each sample, water volume and total phosphorus concentration were determined. The water volume was used to estimate the total ground-water input into the inlet. The product of the water volume and the average total phosphorus concentration should represent the total phosphorus input; however, these values must be adjusted to account for anoxic conditions that developed within the seepage meters. Therefore, this input rate was reduced by subtracting the rate at which phosphorus would be released from the sediments during anoxic conditions (see the section "Laboratory Determination of Phosphorus Release Rates").

\section{Atmosphere}

The daily input of phosphorus from the atmosphere, $\left(\mathrm{P}_{\mathrm{Atm}}\right)$, was assumed to be equal to the average deposition rate during 1984 and 1985 (Field and Duerk, 1988) applied over the entire surface of the inlet.

\section{Sediments of the Inlet}

Phosphorus input from the sediments was determined by means of laboratory and field studies. The laboratory studies were designed to determine phosphorus release rates for oxic and anoxic conditions and for a range in $\mathrm{pH}$. The field studies were designed to provide continuous ambient measurements of dissolved oxygen and $\mathrm{pH}$ near the sediment surface. The total phosphorus release from the sediments was then estimated by calculating the release rates for the specific ambient conditions.

\section{Laboratory Determination of Phosphorus Release Rates}

Replicate sediment cores (nine from each site) were collected from three sampling sites in the inlet and were sent to the laboratory. The upper $10-\mathrm{cm} \mathrm{sec-}$ tion of sediment from each core and filtered water from the inlet were used to construct sediment systems of the type described by James and Barko (1991). Each system was incubated in the dark at a constant $20^{\circ} \mathrm{C}$ (the approximate mean temperature of water in the inlet from April through September). Dissolved orthophosphate concentrations were measured daily in the surficial water above each core for 1 to 2 weeks. The release rate (in milligrams per square meter per day) was calculated as a linear change in the mass of phosphorus in the overlying water divided by product of the time of incubation and the surface area of the core.

Eighteen of the sediment systems (six from each site) were used to determine the oxic and anoxic release rates. In three systems from each site, air was gently bubbled into the surficial water to maintain oxic conditions; in three other systems from each site, nitrogen was bubbled into the surficial water to maintain anoxic conditions. Surficial water above the cores with oxic conditions had a pH of about 8.5 , whereas that above cores with anoxic conditions had a pH of about 9.0. For the remaining nine systems (three from each site), $\mathrm{pH}$ in the surficial water was raised to and maintained at about 9.1 while oxic conditions were maintained by bubbling $\mathrm{CO}_{2}$-free air into the surficial water (Boers, 1991). The equation describing the phosphorus release (in milligrams per square meter per day) under oxic conditions as a function of daily average $\mathrm{pH}$ was assumed to be linear on the basis of studies by James and Barko (1991) and was calculated from the average oxic release rates at $\mathrm{pH}$ of 8.5 and 9.1. (See James and others, 1995, for a complete discussion of laboratory procedures and results.)

\section{Ambient Conditions in Delavan Lake Inlet}

Water temperature, dissolved oxygen, and $\mathrm{pH}$ at the base monitoring site (fig. 1) were measured at 1hour intervals from April 14 through September 30, 1994 , by use of a YSI $6000^{4}$ multiparameter waterquality monitor at a depth of $0.3 \mathrm{~m}$ in about $0.4 \mathrm{~m}$ of water. The base monitoring site was an area of dense vegetation, as was most of the inlet. This monitor was equipped with a YSI Rapid Pulse system for dissolved oxygen measurements. No stirrer was required for the

${ }^{4}$ Use of trade names in this report is for identification purposes only and does not constitute endorsement by the U.S. Geological Survey. 
dissolved oxygen probe, so the water was not mixed or circulated in this shallow environment. To avoid disturbing the bottom sediments when working at the site, field personnel worked from a platform constructed to allow access to data loggers and sampling equipment.

The monitor was cleaned and recalibrated about every 2 weeks. The dissolved oxygen system was calibrated by use of "zero dissolved oxygen" water and the air-calibration method; $\mathrm{pH}$ was calibrated with $\mathrm{pH} 7.00$ and 10.00 buffers. The monitor did not require calibration for water temperature, but field measurements were made to test its accuracy. Readings were made with the calibration standards when the monitor was removed to determine sensor drift during deployment and again when the monitor was reinstalled to determine any starting corrections for the sensor.

In addition to the continuous measurements at the base monitoring site, water temperature, dissolved oxygen, and $\mathrm{pH}$ profiles were measured at approximately $50-\mathrm{cm}$ intervals about every 2 weeks or whenever the water-quality monitor was serviced. Water samples were also collected at $0.1-$ and $0.3-\mathrm{m}$ depths and were analyzed for total phosphorus, dissolved orthophosphate, iron, and manganese. The samples were collected by use of a peristaltic pump and an adjustable-depth sampling post. Depth markings on the sampling post ensured that sequential samples were collected consistently at the same depth and location without major disturbance of sediments and vegetation. An in-line filtering unit was used to filter the water samples in the field for determination of the dissolved constituents. Five times during the study (approximately monthly from May through September 1994), diurnal monitoring was done at the base monitoring site at the same two depths as the biweekly monitoring. In each diurnal series, profile data for water temperature, dissolved oxygen, and $\mathrm{pH}$ were collected at dawn, mid-morning, noon, mid-afternoon, and dusk, and water samples were analyzed for the same constituents as in the biweekly sampling. All analyses were done by the Wisconsin State Laboratory of Hygiene. During each diurnal time series, profile data for water temperature, dissolved oxygen, and $\mathrm{pH}$ were collected at approximately $50-\mathrm{cm}$ intervals at four additional locations (sites 1-4, fig. 1) to determine vertical and spatial variability in ambient conditions.

\section{Computation of Phosphorus Release from the Sediments}

Phosphorus release from the sediments (during anoxia and $\mathrm{pH}$ greater than 8 ) was estimated daily by use of the equations derived from the laboratory experiments (James and others, 1995) and average daily ambient conditions in the inlet. For each day, the average $\mathrm{pH}$ (computed by averaging hourly hydrogen ion concentrations) and the fraction of the day under anoxic conditions (dissolved oxygen concentrations less than $0.5 \mathrm{mg} / \mathrm{L}$ ) were computed. Then for each day, the phosphorus release (in kilograms per day) during anoxic conditions $\left(\mathrm{P}_{\mathrm{SA}}\right)$ was computed as the product of the anoxic release rate from the laboratory experiments $\left(23.0 \mathrm{mg} \mathrm{m}^{-2} \mathrm{~d}^{-1}\right)$, the fraction of the day under anoxic conditions (between 0 and 1.00), and the area of the inlet (eq. 3).

Daily Anoxic Phosphorus Release:

$$
\begin{aligned}
\mathrm{P}_{\mathrm{SA}}= & 23.0 \mathrm{x} \text { fraction of the day under anoxic } \\
& \text { conditions } \mathrm{x} \text { area of the inlet }
\end{aligned}
$$

The total daily release during oxic conditions was computed as the product of the daily oxic release rate as a function of $\mathrm{pH}$ (using the equations derived from the laboratory sediment systems bubbled with air and bubbled with $\mathrm{CO}_{2}$-free air), the fraction of the day under oxic conditions (fraction oxic, between 0 and 1.00), and the area of the inlet (eq. 4).

Daily Oxic Phosphorus Release:

$\mathrm{P}_{\mathrm{SO}}=(6.2 \mathrm{x}$ average daily $\mathrm{pH}-49.9) \times$ fraction oxic $x$ area of the inlet

\section{PHOSPHORUS DYNAMICS}

\section{Background Streamflow and Water- Quality Data}

Streamflow. Daily average streamflow into Delavan Lake Inlet is shown in figure 4. The highest daily flow, about $1.2 \mathrm{~m}^{3} / \mathrm{s}$, was recorded in late April. Other high flows were recorded in late June and throughout August.

Water Quality at the Base Monitoring Site. Daily average water temperatures in the inlet increased from about $12^{\circ} \mathrm{C}$ in mid-April to almost $30^{\circ} \mathrm{C}$ in midJune (fig. 4). Daily average water temperatures then fluctuated between $20^{\circ} \mathrm{C}$ and $30^{\circ} \mathrm{C}$ until mid-September, when temperatures began to steadily decrease to 

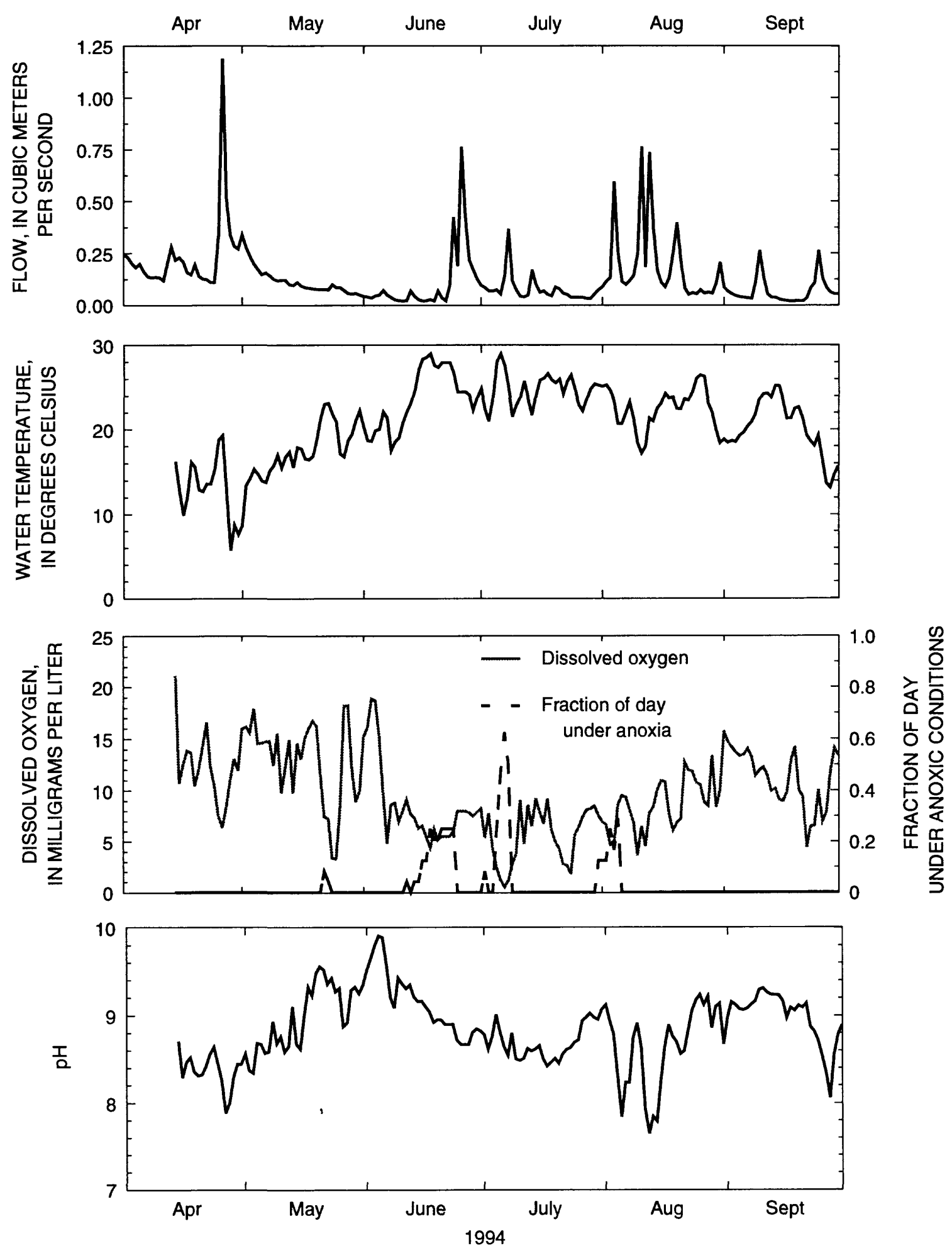

Figure 4. Daily average flow at Mound Road and daily average water temperature, dissolved oxygen, and $\mathrm{pH}$ at the base monitoring site in Delavan Lake Inlet, Wisconsin, April 1-September 30, 1994. 


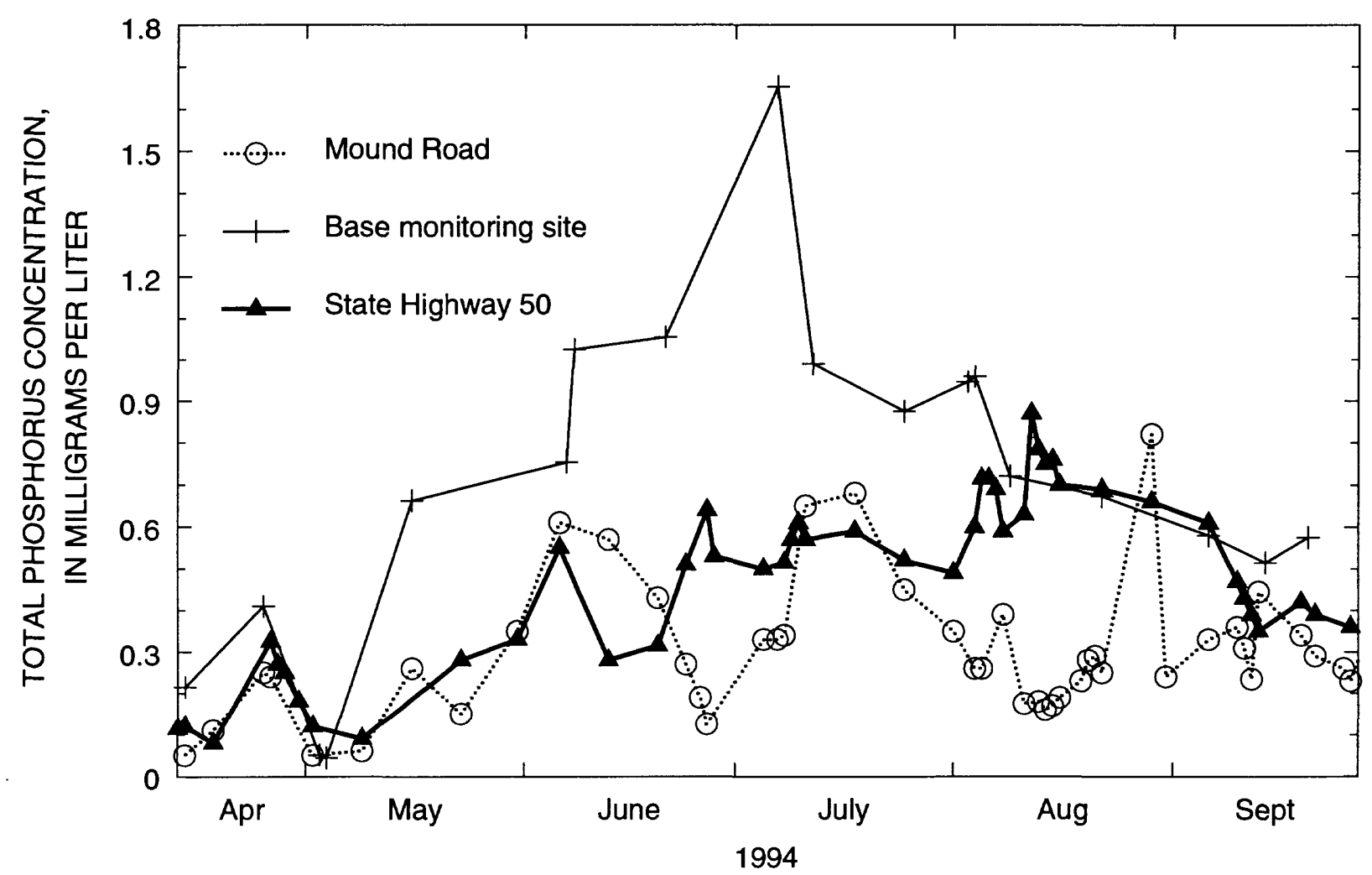

Figure 5. Total phosphorus concentrations in Delavan Lake Inlet, Wisconsin, April 14-September 30, 1994.

about $15^{\circ} \mathrm{C}$ by the end of September. The average water temperature for this entire period was about $21^{\circ} \mathrm{C}$. Superimposed on this semi-annual pattern was a daily cycle of about $6^{\circ} \mathrm{C}$.

Average daily dissolved oxygen concentrations in the inlet fluctuated from about 4 to $20 \mathrm{mg} / \mathrm{L}$ from mid-April to about the end of May (fig. 4). In late April and late May, dissolved oxygen concentrations decreased for short periods when surface temperatures were increasing. Concentrations then decreased dramatically in the beginning of June and fluctuated between 1 and $8 \mathrm{mg} / \mathrm{L}$ until early August. Daily average concentrations reached a minimum of about $0.5 \mathrm{mg} / \mathrm{L}$ at the beginning of July (concentrations were below $0.5 \mathrm{mg} / \mathrm{L}$ more than 60 percent of the day). Daily average concentrations then steadily increased to about the beginning of September, thereafter fluctuating between 5 and $15 \mathrm{mg} / \mathrm{L}$. Superimposed on these seasonal variations was a large daily cycle in concentrations, which were lowest just before sunrise and highest in mid-morning. Concentrations commonly dropped to below $0.5 \mathrm{mg} / \mathrm{L}$ for a few minutes each day from mid-May to mid-August; however, only during three short periods (mid-June, beginning of July, and beginning of August) were concentrations less than $0.5 \mathrm{mg} / \mathrm{L}$ for more than about five hours a day.

The $\mathrm{pH}$ in the inlet was 8 or higher during most of the time during the study period (fig. 4). In midApril, the daily average $\mathrm{pH}$ was about 8.5 ; it increased thereafter and peaked at about 10 in the beginning of June. The pH then fluctuated between 8.5 and 9.2 throughout the rest of the summer; however, during two periods, $\mathrm{pH}$ dropped to about 8 . Superimposed on these seasonal changes was a daily cycle in $\mathrm{pH}$, which was lowest just before sunrise (when dissolved oxygen concentrations were lowest) and highest in mid-morning (when dissolved oxygen concentrations were highest).

Total phosphorus concentrations at the base monitoring site (fig. 5) were about $0.2 \mathrm{mg} / \mathrm{L}$ in midApril then increased to about $0.4 \mathrm{mg} / \mathrm{L}$ by late April then decreased to about $0.05 \mathrm{mg} / \mathrm{L}$ in early May because of high flow (fig. 4). Concentrations then steadily increased to about $1.0 \mathrm{mg} / \mathrm{L}$ in early June. Concentrations then remained fairly constant until mid-August, except for one high concentration (about 
$1.7 \mathrm{mg} / \mathrm{L}$ ) in early July. Concentrations then gradually decreased to about $0.5 \mathrm{mg} / \mathrm{L}$ in mid-September.

Water Quality Throughout the Inlet. In general, the biweekly water-quality data collected at other sites in the inlet (fig. 1) were similar to those from the base monitoring site, and the stratification of water temperature, dissolved oxygen, and $\mathrm{pH}$ were fairly similar throughout the inlet.

Total phosphorus concentrations were measured at the base monitoring site, at Mound Road (input to the inlet), and at State Highway 50 (output from the inlet). Total phosphorus concentrations differed consistently among the sites. Concentrations entering the inlet at Mound Road and leaving the inlet at State Highway 50 were consistently lower than those at the base monitoring site (fig. 5). In general, concentrations leaving the inlet were higher than those entering the inlet during late June through early July and from late July through early September.

\section{Phosphorus Inputs, by Source, April through September 1994}

\section{Runoff from Gaged and Ungaged Areas}

Runoff from upstream of Mound Road (gaged area) was the major source of phosphorus to the inlet during short-term high flows (fig. 6). High flows occurred in most months and resulted in the gaged area being a significant source of phosphorus in all months; this area contributed between 24 percent (May and June) and 50 percent (April) of the total input of phosphorus. The total load of phosphorus to the inlet in April was smaller than in other months because only part of the month was included in the budget (April 1430 ). The gaged area contributed $383.6 \mathrm{~kg}$ of total phosphorus ( 36.1 percent of the total input) to the inlet from April through September (table 2; fig. 7).

Most of the phosphorus loading from the ungaged area (direct runoff into the inlet) also was contributed during short-term high flows (fig. 6). This area contributed between 2 percent (July and September) and 23 percent (latter half of April) of the total input of phosphorus. The ungaged area contributed $76.9 \mathrm{~kg}$ of total phosphorus to the inlet (7.2 percent of the total input) from April through September (table 2; fig. 7).

\section{Ground Water}

Input of phosphorus from ground water was negligible in comparison to that contributed by the release from the sediments during anoxia or $\mathrm{pH}$ greater than 8 . The phosphorus in the seepage meters was entirely accounted for by release for sediments under the anoxic conditions present.

\section{Atmosphere}

Input of phosphorus onto the inlet from the atmosphere was estimated to be less than $1 \mathrm{~kg}$ per month, or a total of $4.2 \mathrm{~kg}$ from April through September (table 2 ). This amount represented less than 1 percent of the total input during any month and 0.4 percent of the total input of phosphorus (fig. 7).

\section{Sediments of the Inlet}

Phosphorus release from the sediments was divided into that released during anoxic and oxic conditions. For each day, the fraction of the day that inlet water was anoxic (dissolved oxygen concentration less than $0.5 \mathrm{mg} / \mathrm{L}$ ) and a daily average $\mathrm{pH}$ were calculated. Then, equations 3 and 4 were used to estimate the total input of phosphorus.

Anoxic Phosphorus Release. Although dissolved oxygen concentrations commonly dropped below $0.5 \mathrm{mg} / \mathrm{L}$ for short periods daily during mid-May to mid-August, anoxic periods of more than about 5 hours occurred only during three short periods, midJune, early July, and early August (fig. 4). Therefore, the release of phosphorus during anoxia was significant only during June through August (fig. 6). The anoxic release of phosphorus contributed from 0 percent (April and September) to 14 and 15 percent (June and July) of the total input. The anoxic release of phosphorus contributed $76.1 \mathrm{~kg}$ of total phosphorus ( 7.2 percent of the total input) to the inlet from April through September (table 2; fig. 7).

Oxic Phosphorus Release. As a result of high $\mathrm{pH}(8$ to 10$)$ throughout the summer, the release of phosphorus from the sediments during oxic conditions was the single largest source of phosphorus to the inlet from May through September (fig. 7). The oxic release of phosphorus contributed from 26 percent (latter half of April) to 72 percent (May) of the total input of phosphorus (fig. 6). The oxic release of phosphorus contributed $521.5 \mathrm{~kg}$ of total phosphorus (49.1 percent of the 



Figure 6. Total phosphorus loading into Delavan Lake Inlet, Wisconsin summarized by day and month. [Apr ${ }^{1}$ represents the loading from April 14-30.] 
Table 2. Detailed phosphorus budget for Delavan Lake Inlet, Wisconsin, April 14-September 30, 1994 [All data in kilograms]

\begin{tabular}{|c|c|c|c|c|c|c|c|c|c|}
\hline \multirow{3}{*}{ Month } & \multirow{3}{*}{ 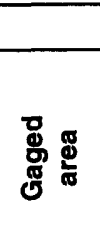 } & \multirow{3}{*}{ 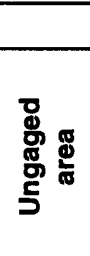 } & \multicolumn{4}{|c|}{ Inputs } & \multirow{3}{*}{ बूँ } & \multirow[t]{3}{*}{ Output } & \multirow{3}{*}{$\begin{array}{c}\text { Change } \\
\text { in } \\
\text { storage }\end{array}$} \\
\hline & & & & \multirow{2}{*}{ 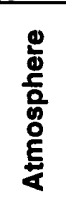 } & \multicolumn{2}{|c|}{$\begin{array}{c}\text { Released from } \\
\text { sediments } \\
\end{array}$} & & & \\
\hline & & & 这 & & $\begin{array}{l}\frac{0}{X} \\
\frac{0}{c} \\
\frac{c}{\alpha}\end{array}$ & $\frac{u}{x}$ & & & \\
\hline April & 44.1 & 20.5 & 0.0 & 0.4 & 0.0 & 22.9 & 87.9 & 101.8 & -13.9 \\
\hline May & 37.0 & 4.0 & .0 & .8 & 1.8 & 113.5 & 157.1 & 68.6 & 88.5 \\
\hline June & 54.3 & 13.7 & .0 & .7 & 30.1 & 124.0 & 222.7 & 186.5 & 36.2 \\
\hline July & 86.7 & 4.6 & .0 & .8 & 30.1 & 74.1 & 196.3 & 145.1 & 51.2 \\
\hline August & 117.0 & 30.8 & .0 & .8 & 14.1 & 75.5 & 238.2 & 471.4 & -233.2 \\
\hline September & 44.5 & 3.2 & .0 & .7 & .0 & 111.6 & 160.0 & 107.3 & 52.7 \\
\hline Total & 383.6 & 76.9 & .0 & 4.2 & 76.1 & 521.5 & $1,062.3$ & $1,080.8$ & -18.5 \\
\hline Percent of total input & 36.1 & 7.2 & .0 & .4 & 7.2 & 49.1 & 100.0 & 101.7 & 1.7 \\
\hline
\end{tabular}

total input) to the inlet from April through September (table 2).

\section{Total Phosphorus Input to and Output from Delavan Lake Inlet, April through September 1994}

The estimated total input of phosphorus into Delavan Lake Inlet during April 14 through September 30,1994 , was $1,062.3 \mathrm{~kg}$ (table 2 ). The cumulative input of total phosphorus to the inlet (fig. 8) is virtually constant, as indicated by a linear cumulation throughout the summer. The high input of phosphorus from runoff-producing storms (fig. 6) is barely discernible in figure 8 .

Approximately $1,081 \mathrm{~kg}$ of total phosphorus was output from Delavan Lake Inlet into Delavan Lake during April 14-September 30, 1994 (table 2). Nearly 80 percent $(828 \mathrm{~kg})$ of the phosphorus delivered from the inlet into Delavan Lake was in the form of dissolved orthophosphate (Holmstrom and others, 1995) compared to approximately 20 percent in 1985 (Holmstrom and others, 1986). The cumulative output from the inlet is shown in figure 8. During the entire period, the output of phosphorus into Delavan Lake is about equal to that estimated to be input into the water column of Delavan Lake Inlet. The change in storage $(\Delta S)$ over the entire period is estimated to be a decrease of only $18.5 \mathrm{~kg}$ (1.7 percent of the total input, table 2). Most of the output of phosphorus was during three high flows, in late April, late June, and early August; for example, during four days in mid-August 1994, more than $170 \mathrm{~kg}$ of phosphorus (90 percent as dissolved orthophosphate) was delivered to Delavan Lake. These high flows show as steep increases in the cumulative output curve in figure 8.

\section{Relative Importance of Sources of Phosphorus to Delavan Lake Inlet, April through September 1994}

From April through September, release of phosphorus from sediments was the most important source of phosphorus to the inlet and, ultimately, to Delavan Lake (fig. 7). The sediments were the source of 56 percent of the entire input to the inlet during the period. Most of this release was due to the high pH's in the inlet, which were probably caused by photosynthetic activity of the extensive macrophyte community. The $\mathrm{pH}$ was highest during the early part of summer, when macrophytes were growing most rapidly, and at midmorning, when dissolved oxygen concentrations were highest in the inlet. During April through September, runoff from the watershed (upstream from the inlet and direct runoff) was the source of about 43 percent of the total input. Input of phosphorus from ground water and from atmospheric deposition were negligible compared to that from other sources. 


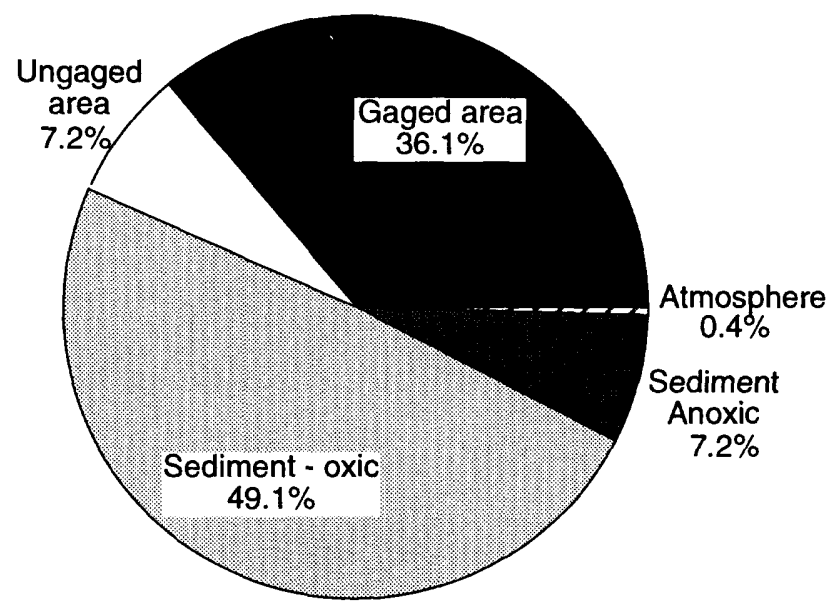

April 14-September 30, 1994

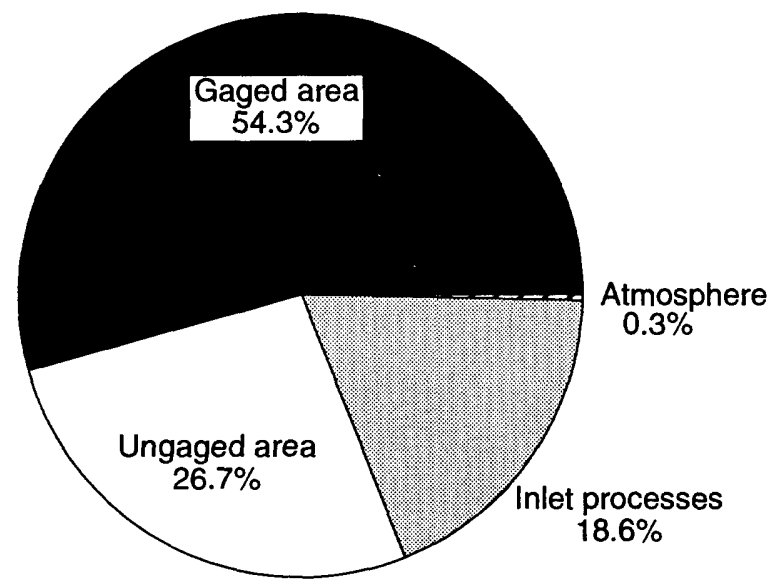

October 1, 1993-September 30, 1994

Figure 7. Summary of total phosphorus budget for Delavan Lake Inlet, Wisconsin, April 14-September 30, 1994, and October 1, 1993-September 30, 1994.

\section{Accuracy of April through September Phosphorus Budget}

Error is inherent in each of the terms in the detailed phosphorus budget (eq. 1), but these errors are difficult to quantify independently. One can, however, examine the entire phosphorus budget by comparing the change in storage term $(\Delta S)$ in equation 1 with the measured change in storage within the inlet.

The $\Delta \mathbf{S}$ for April through September was about $-19 \mathrm{~kg}$. Thus, the average total phosphorus concentration should have decreased by about $0.05 \mathrm{mg} / \mathrm{L}(19 \mathrm{~kg}$ of phosphorus removed from $378,000 \mathrm{~m}^{3}$, the total volume of the inlet). The initial total phosphorus concentra- tion in the inlet was between 0.12 (State Highway 50) and $0.22 \mathrm{mg} / \mathrm{L}$ (base monitoring site), so the ending concentration in the inlet should have been between 0.07 and $0.17 \mathrm{mg} / \mathrm{L}$. However, the measured concentration in the inlet in late September increased and was between $0.36 \mathrm{mg} / \mathrm{L}$ (State Highway 50 ) and $0.58 \mathrm{mg} / \mathrm{L}$ (base monitoring site). From mid-April through the end of September, total phosphorus concentrations increased between 0.24 and $0.46 \mathrm{mg} / \mathrm{L}$; therefore, the overall increase in storage should have been between 91 and $174 \mathrm{~kg}$. An additional input of between 110 and $193 \mathrm{~kg}$ of phosphorus into the inlet seems to have been unaccounted for in the detailed budget (discussed later). The additional inputs required to balance the budget equates to a net error in inputs versus outputs of between 9 and 15 percent, assuming the beginning and ending concentrations at the base monitoring site and at State Highway 50 were without error.

The $\Delta S$ term may also be used to estimate average daily concentrations for April through September (fig. 9). Daily values for $\Delta S$ can be estimated from the difference in the phosphorus input to the inlet (from gaged and ungaged areas, sediments, and atmospheric deposition) and the phosphorus output from the inlet at State Highway 50. Where the cumulative output curve drops below the input curve (fig. 8), phosphorus should build up in the inlet, and concentrations should increase. From the middle of May through the middle of August the output curve dropped below the input curve, an indication that concentrations should have increased in the inlet. Where the output curve rises above the input curve, concentrations in the inlet should drop below the initial concentration. A continuous time series of average concentrations in the inlet was constructed by use of equation 5 ,

$[\mathrm{TP}]_{\text {Day } t+1}=[\mathrm{TP}]_{\text {Day } \mathrm{t}}+\Delta \mathrm{S} /$ Volume of the inlet,

where [TP] is the average total phosphorus concentration in the inlet (fig. 9).

The estimated concentrations agree closely with the concentrations measured at State Highway 50 except for mid-August through mid-September (fig. 9). (The concentration at the outlet at Highway 50 integrates all the processes within the inlet.) The estimated concentrations decrease in early May, increase throughout May and June, remain steady throughout July and early August, and then decrease through midSeptember. The estimated concentrations, however, decreased much more rapidly in response to the high flows in mid-August, whereas measured concentra- 


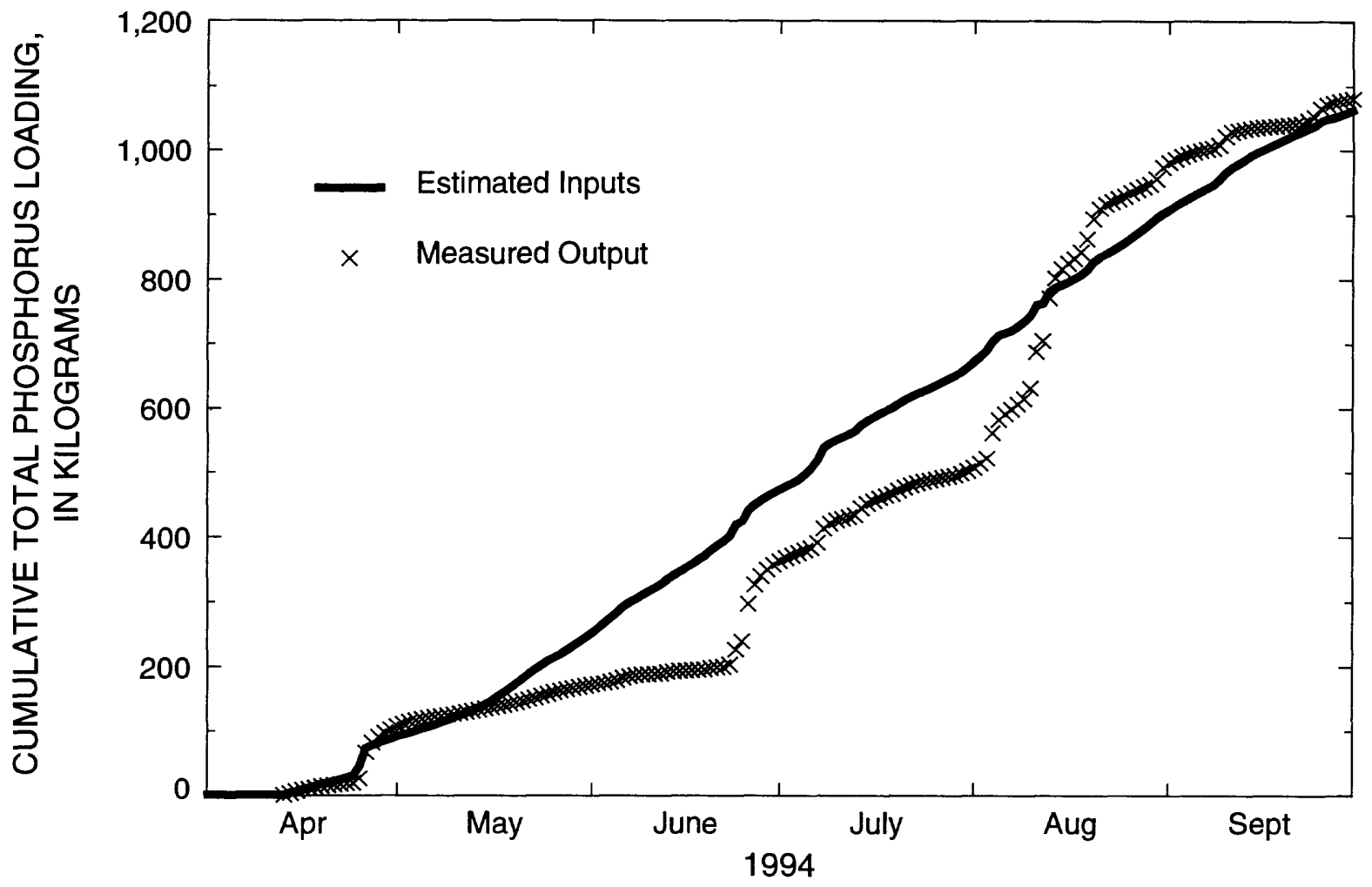

Figure 8. Cumulative phosphorus loading into and out of Delavan Lake Inlet, Wisconsin, April 14-September 30 , 1994.

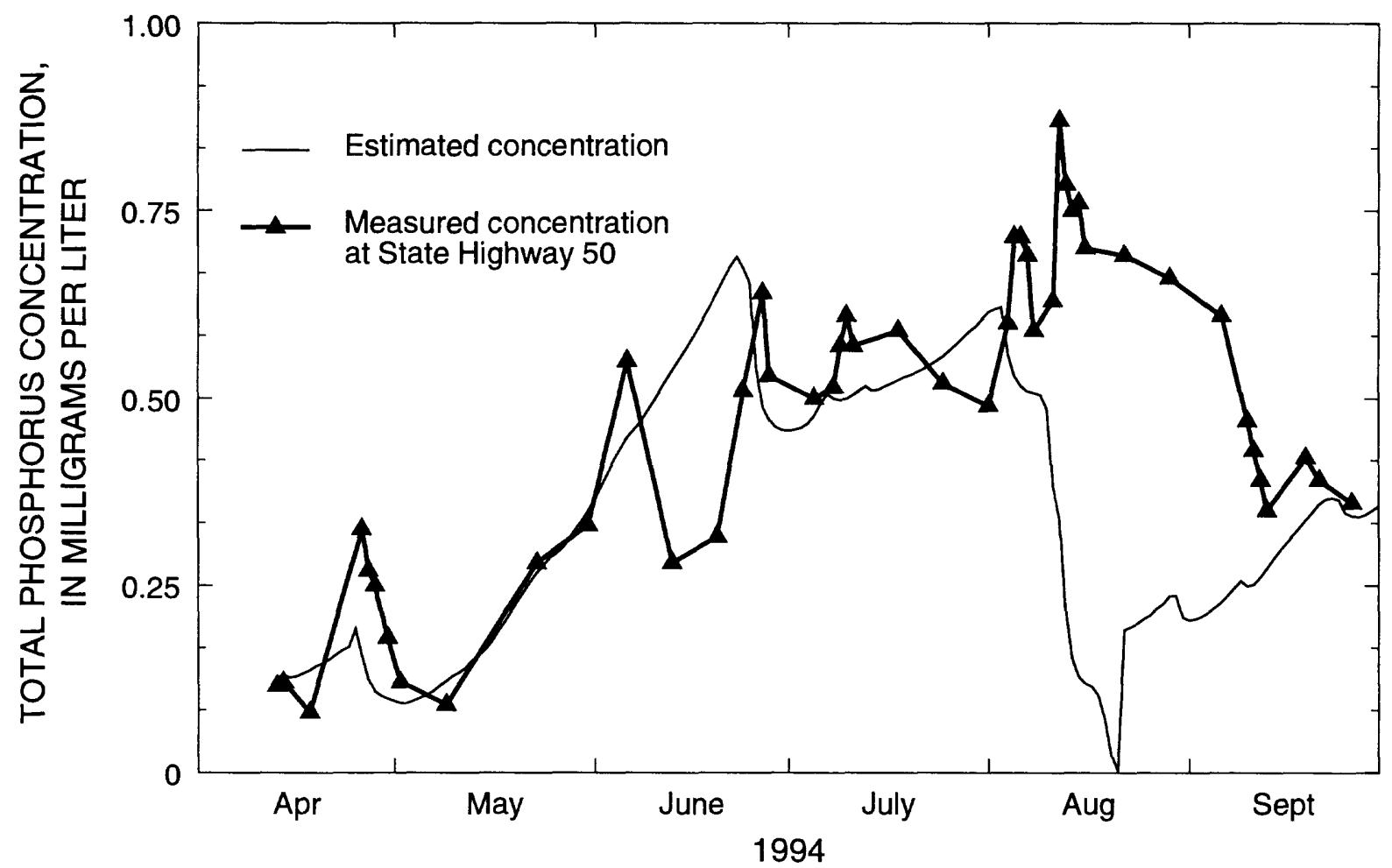

Figure 9. Measured and estimated total phosphorus concentrations in Delavan Lake Inlet, Wisconsin, April 14September 30, 1994. 
tions remained steady or increased. This discrepancy is discussed later in this section. The measured phosphorus output from the inlet during the mid-August high flows was greater than the amount of phosphorus contained in the water of the entire inlet. When all of the phosphorus contained in the inlet was removed, the average concentration in equation 5 was set equal to the concentration measured upstream at Mound Road and daily computations of concentrations were continued.

The general agreement between the estimated and measured concentrations throughout most of the summer indicate that the overall input and output of phosphorus into the water column of Delavan Lake Inlet was fairly accurate. Because the $\Delta S$ over the entire period was very small (1.7 percent of the total input; fig. 8), one can conclude that almost all the input of phosphorus into the water column of the inlet was transferred to Delavan Lake.

Slightly more phosphorus was estimated to have been output from the inlet than was input to it (approximately $19 \mathrm{~kg}$; fig. 8); therefore, concentrations should have decreased. Measured concentrations increased however by between 0.24 and $0.46 \mathrm{mg} / \mathrm{L}$. The discrepancy between the estimated daily changes in total phosphorus and measured concentrations may have been due to the high flows in mid-August. During these high flows, the inputs of phosphorus may have been underestimated or the outputs overestimated, or an unidentified source may have contributed phosphorus. This additional input of phosphorus may have come from erosion of the inlet sediments or from the senescence of the macrophytes in the inlet (not included in the budget).

James and others (1995) estimated that during the growing season of 1994, the macrophytes in the inlet ( 70 percent of which were rooted) incorporated about $600 \mathrm{~kg}$ of phosphorus into their tissues. Most of the uptake of phosphorus from rooted macrophytes is from the sediments; therefore, about $400 \mathrm{~kg}$ of additional phosphorus uptake from the sediments should have occurred. Part of this phosphorus could potentially be recycled into the water column during senescence (Carpenter, 1980; Smith and Adams, 1986) and may account for the additional 91 to $174 \mathrm{~kg}$ of phosphorus.

\section{Importance of the April through September Loading to the Annual Phosphorus Load to Delavan Lake}

A less-detailed phosphorus budget was prepared for February 1993 through September 1994 (table 3) to determine the importance of the April-September period to the total annual phosphorus budget during a near normal runoff year (1994) and a high runoff year (1993) and to determine how the sources vary in importance during these periods. In the less-detailed budget (eq. 2), the input of phosphorus from the sediment (oxic and anoxic) and the change in storage terms were lumped into one term-the change in phosphorus throughout the inlet ( $\Delta$ Inlet)-which was computed by use of equation 6 .

$$
\Delta \text { Inlet }=P_{\text {Out }}-P_{G}-P_{U G}-P_{G W}-P_{\text {Atm }}
$$

Because the change in storage was shown to be small over the entire summer, and the $\Delta$ Inlet term applies mostly to sediment processes, and possibly to erosional processes during high flows, it is referred to as "inlet processes." Monthly values for each of the terms in equation 6, and seasonal (April through September) and annual summaries are given in table 3 . The annual phosphorus budget for the entire water year 1994 is compared to that for April through September in figure 7 to demonstrate the change in relative importance of the individual components of the budget.

The input of phosphorus from April through September represented about 40 percent of the total annual input during water year 1994 (table 3). During the other months (October 1993 through March 1994), input from the gaged and ungaged areas was the major source of phosphorus. In fact, during October through March, inlet processes were a net sink for phosphorus, owing to a net loss of phosphorus (deposition) in the inlet during high flow in February 1994. Thus, for the entire year, the inlet generated only 19 percent of the total phosphorus input during this near normal runoff year (fig. 7). During the high runoff year (February through September 1993), the input of phosphorus from the inlet was even a smaller component of the budget ( 6 percent of the total phosphorus). (Data were only available for 8 months of 1993, but were included here to demonstrate the maximum contribution of inlet processes in a high runoff year. The actual contribution of inlet processes in water year 1993 should be less than 6 percent of the total budget.) During the late win- 
Table 3. Phosphorus budget for Delavan Lake Inlet, Wisconsin, February 1993-September 1994 [Data are in kilograms except for numbers in the parentheses, which are percentage of the total phosphorus budget]

\begin{tabular}{|c|c|c|c|c|c|}
\hline \multirow{2}{*}{ Date } & \multicolumn{4}{|c|}{ Inputs } & \multirow[b]{2}{*}{ Output } \\
\hline & $\begin{array}{c}\text { Gaged } \\
\text { area }\end{array}$ & $\begin{array}{c}\text { Ungaged } \\
\text { area }\end{array}$ & Atmosphere & $\begin{array}{c}\text { Inlet } \\
\text { processes }\end{array}$ & \\
\hline \multicolumn{6}{|l|}{1993} \\
\hline February & 81 & 45 & 1 & -28 & 154 \\
\hline March & 1,370 & 548 & 1 & -443 & 1,477 \\
\hline April & 2,204 & 507 & 1 & -757 & 1,955 \\
\hline May & 76 & 37 & 1 & 187 & 301 \\
\hline June & 513 & 280 & 1 & 471 & 1,265 \\
\hline July & 221 & 119 & 1 & 724 & 1,065 \\
\hline August & 38 & 10 & 1 & 106 & 156 \\
\hline September & 75 & 36 & 1 & 59 & 172 \\
\hline October & 9 & 4 & 1 & 13 & 27 \\
\hline November & 14 & 7 & 1 & 2 & 24 \\
\hline December & 11 & 5 & 1 & 1 & 18 \\
\hline \multicolumn{6}{|l|}{1994} \\
\hline January & 3 & 2 & 1 & 8 & 14 \\
\hline February & 863 & 525 & 1 & -154 & 1,235 \\
\hline March & 185 & 80 & 1 & 38 & 304 \\
\hline April & 54 & 36 & 1 & 33 & 124 \\
\hline May & 37 & 4 & 1 & 27 & 69 \\
\hline June & 54 & 14 & 1 & 118 & 187 \\
\hline July & 87 & 5 & 1 & 53 & 145 \\
\hline August & 117 & 43 & 1 & 310 & 472 \\
\hline September & 45 & 3 & 1 & 59 & 107 \\
\hline \multicolumn{6}{|l|}{ Summaries } \\
\hline April-September 1994 & $394(35.7)$ & $105(9.5)$ & $5(0.4)$ & $599(54.3)$ & 1,103 \\
\hline April-September 1993 & $3,127(63.7)$ & $990(20.2)$ & $5(0.3)$ & $791(16.1)$ & 4,912 \\
\hline October 1993-September 1994 & $1,480(54.3)$ & $728(26.7)$ & $9(0.3)$ & $508(18.6)$ & 2,725 \\
\hline February-September 1993 & $4,578(70.0)$ & $1,584(24.2)$ & $6(0.1)$ & $376(5.7)$ & 6,543 \\
\hline
\end{tabular}

ter and early spring high flows of 1993, net deposition of phosphorus into the inlet was greater than $1,200 \mathrm{~kg}$.

During April through September of the high runoff year of 1993, phosphorus input from the gaged and ungaged areas was a major component of the budget, almost 85 percent of the total input (table 3). The total phosphorus input from these areas during the high runoff year $(4,117 \mathrm{~kg} ; 3,127$ from gaged areas and $990 \mathrm{~kg}$ from ungaged areas) increased by more than a factor of 8 from that in the near normal runoff year $(499 \mathrm{~kg} ; 394$ $\mathrm{kg}$ from gaged areas and $105 \mathrm{~kg}$ from ungaged areas), whereas phosphorus input from inlet processes increased only slightly (by a factor of about 1.3) during the high runoff year. This small increase in loading from inlet processes might be expected as a result of high flows and more flushing in the inlet, which would lower phosphorus concentrations and increase the phosphorus gradient between the sediments and the water column. Continuous dissolved oxygen and $\mathrm{pH}$ data for directly estimating the inputs were not available for 1993 .

The input of phosphorus from the inlet may have a strong effect on Delavan Lake. Field and Duerk (1988) stated that the total phosphorus from external 
loading during 1984 and 1985 was sufficient to be classified as "dangerous" according to Vollenweider's model $(1971,1975)$, and that this loading of phosphorus should result in eutrophication of Delavan Lake. Since 1991, the external loading of phosphorus has been similar to or higher than that in 1984 and 1985; therefore, external loading is still sufficient to maintain eutrophy in Delavan Lake.

\section{Importance of Macrophytes to the Phosphorus Budget}

Part of the phosphorus that is incorporated into the tissues of rooted vegetation may be recycled into the water column during senescence (Carpenter, 1980; Smith and Adams, 1986). Most of this release occurs during late summer and fall. On the basis of the detailed phosphorus budget, phosphorus release from the macrophytes during August could have been about 100 to $200 \mathrm{~kg}$, although senescence of most of the macrophytes found in Delavan Lake Inlet should occur later in the fall (J. Madson, U.S. Army Corps of Engineers, Lewisville, Texas, oral commun., 1996). Inlet processes from October 1993 through January 1994 generated less than $25 \mathrm{~kg}$ of phosphorus, and does not account for additional loss from senescence later in the fall. Therefore, about 25 to 50 percent of the phosphorus taken up by the macrophytes ( 100 to $200 \mathrm{~kg}$ of the total estimated $400 \mathrm{~kg}$ taken up by the macrophytes) may be released into the water column. The remainder of the phosphorus incorporated into the macrophytes may be resorbed or may fall to the surface of the sediments. Some of this phosphorus may be released later during periods of high $\mathrm{pH}$ or anoxia.

Macrophyte metabolism significantly affects the $\mathrm{pH}$ of the inlet. The highest seasonal pH's were observed during early summer when the macrophytes were growing rapidly, and the highest $\mathrm{pH}$ 's during the day were observed during mid-morning when the dissolved oxygen concentrations (an indicator of metabolism) were highest. Therefore, although the macrophytes seem to release a small proportion of phosphorus, they appear to add phosphorus to the surface sediment and increase the $\mathrm{pH}$ of the inlet significantly.

\section{CONCLUSIONS}

Since 1991, median total phosphorus concentrations in Delavan Lake Inlet (May through October) have increased to more than those from 1984 through 1990 , even though various remedial actions have been taken upstream. Dissolved orthophosphorus represented about 20 percent of the total phosphorus in 1985 compared to about 80 percent in 1994. This increase in concentrations and change in speciation coincided with the removal of rough fish and the transformation of Delavan Lake Inlet from a turbid-water system with few macrophytes to a clear-water system with an abundance of macrophytes. The clear water associated with the removal of rough fish has apparently enabled macrophytes to grow in abundance, which in turn has increased the $\mathrm{pH}$ of the water in the inlet. The increased $\mathrm{pH}$ has resulted in the release of additional phosphorus from the sediments during April through September. The release of phosphorus from the sediments of Delavan Lake Inlet is the largest source of phosphorus in spring and summer during years of low to near normal runoff; however, during years of high runoff, phosphorus input from its drainage basin is the largest source of phosphorus. Over the entire year, runoff from the drainage basin is the dominant source of phosphorus. During 1994, with near normal runoff, the drainage basin was the source of more than 75 percent of the annual load of phosphorus; during 1993, with high runoff, the drainage basin was the source of more than 90 percent of the annual load of phosphorus.

The input of phosphorus from the inlet may have a strong effect on Delavan Lake. External loading of total phosphorus during 1984 and 1985 was estimated to be excessive and sufficient to maintain eutrophy in the lake. Since 1991, the annual external loading of phosphorus has been similar to or higher than that in 1984 and 1985; therefore, external loading is still sufficient to maintain eutrophy in Delavan Lake. During April through September, the input of phosphorus from the inlet may especially affect Delavan Lake, because almost 80 percent of the phosphorus loading during this time is in the form of dissolved orthophosphate or dissolved reactive phosphorus. This form of phosphorus is readily available to the macrophytes and phytoplankton in Delavan Lake. Most of the phosphorus enters Delavan Lake during high flows; for example, during four days in mid-August 1995, more than 170 $\mathrm{kg}$ of phosphorus (over 90 percent as dissolved orthophosphate) was delivered to Delavan Lake. Therefore, the high flows, which deliver the phosphorus that has been accumulating in the inlet, may stimulate macrophyte growth and algal blooms in Delavan Lake. 


\section{REFERENCES CITED}

Boers, P.C.M., 1991, The influence of $\mathrm{pH}$ on phosphate release from sediments: Water Resources Research, v. 25 , p. $309-311$.

Carpenter, S.R., 1980, Enrichment of Lake Wingra, Wisconsin, by submersed macrophyte decay: Ecology, v. 61, p. 1145-1155.

Field, S.J. and Duerk, M.D., 1988, Hydrology and water quality of Delavan Lake in southeastern Wisconsin: U.S. Geological Survey Water-Resources Investigations Report 87-4168, 61 p.

Fishman, M.J. and Friedman, L.C., 1988, Methods for determination of inorganic substances in water and fluvial sediments: U.S. Geological Survey Techniques of Water-Resources Investigations, book 5, chap. A1, $545 \mathrm{p}$.

Guy, H.P. and Norman, V.W., 1970, Field methods for measurement of fluvial sediment: U.S. Geological Survey Techniques of Water-Resources Investigations, book 3, chap. C2, 59 p.

Helsel, D.R., and MacKinnon, K.L., Final report for the Delavan Lake rehabilitation project, Town of Delavan, Walworth County, Wisconsin: Wisconsin Department of Natural Resources and Delavan Lake Sanitary District [variously paginated].

Holmstrom, B.K., Kammerer, P.A., Jr., and Ellefson, B.R., 1994, Water resources data-Wisconsin, water year 1993: U.S. Geological Survey Water-Data Report WI93-2, $406 \mathrm{p}$.

Holmstrom, B.K., Kammerer, P.A., Jr., and Ellefson, B.R., 1995, Water resources data-Wisconsin, water year 1994: U.S. Geological Survey Water-Data Report WI94-2, $388 \mathrm{p}$.

Holmstrom, B.K., Kammerer, P.A., Jr., and Erickson, R.M., 1986, Water resources data-Wisconsin, water year 1985: U.S. Geological Survey Water-Data Report WI85-1, $414 \mathrm{p}$.

James, W.F., and Barko, J.W., 1991, Estimation of phosphorus exchange between littoral and pelagic zones during nighttime convective circulation: Limnology and Oceanography, v. 36, p. 179-187.
James, W.F., Smith, C.S., Barko, J.W., and Field, S.J., 1995, Direct and indirect influences of aquatic macrophyte communities on phosphorus mobilization from sediments of an inlet region to Delavan Lake, Wisconsin: Technical Report W-95-2, Vicksburg, Miss., U.S. Army Corps Engineers Technical Report, U.S. Army Engineer Waterways Experiment Station, 26 p.

Porterfield, George, 1972, Computation of fluvial-sediment discharge: U.S. Geological Survey Techniques of Water-Resources Investigations, book 3, chap. C3, $66 \mathrm{p}$.

Smith, C.S., and Adams, M.S., 1986, Phosphorus transfer from sediments by Myriophyllum spicatum: Limnology and Oceanography, v. 31, p. 1312-1321.

Vollenweider, R.A., 1971, Scientific fundamentals of eutrophication of lakes and flowing waters, with particular reference to nitrogen and phosphorus as factors in eutrophication: Paris, Organization for Economic Cooperation and Development, $159 \mathrm{p}$.

Vollenweider, R.A., 1975, Input-output models with special reference to the phosphorus loading concept in limnology: Schweizerische Zeitschrift fur Hydrogie, v. 37, no. 1, p. 58-84.

Wisconsin Department of Natural Resources, 1989, Environmental impact statement on the Delavan Lake rehabilitation project, Walworth County, Wisconsin: Wisconsin Department of Natural Resources, Bureau of Environmental Analysis and Review, 199 p.

U.S. Environmental Protection Agency, 1974, Report on Delavan Lake, Walworth County, Wisconsin: U.S. Environmental Protection Agency, Region V, EPA Region V Working Paper 36; 17 p.

U.S. Environmental Protection Agency, 1977, Guidelines for the pollutional classification of Great Lakes Harbor sediments: Environmental Protection Agency Region V. 